\section{Realities of leprosy control: updating scenarios}

\section{Realidades do controle da hanseníase: atualizando cenários}

\section{Aguinaldo Gonçalves'}

'Grupo de Pesquisa: Epidemiologia e Saúde, Faculdade de Medicina da Pontifícia Universidade Católica de Campinas - Campinas (SP), Brazil.

\section{Abstract}

In the light of successive therapeutical difficulties for leprosy control, the application of drug therapy combination over the last decades has brought about an expectation of cure for leprosy patients and also for the elimination of this illness as a Public Health problem. However, there has been a progressive reduction in the prevalence of leprosy, but without any apparent impact on transmission, which has led to recognized need for solid assessment of respective epidemiological evidence as grounds for interventions to solve the problem. In this regard, here we present a retroanalytical qualitative and quantitative study, combined with a prospective diachronic approach, based on the association of documental review techniques and analysis of content, involving the following phases in succession: assembly of an operational scheme, execution of search strategy, application of criteria, selection of studies, data extraction and processing, implementation of analysis plan and preparation of final text. The appropriate execution of the procedures, as applied, allows us to obtain and discuss the identification of three main scenarios: the elimination of the illness as a public health problem (Neglected Illness); therapeutic aspects (Resistance; Relapse; Non-Adherence; Persistence) and complexity (complications and physical incapacities). The conclusions that have been reached indicate,mainly, that the reality of leprosy control with the use of combination drug therapy, still needs to be handled with care, even more so as this is just a fragment of the set of people once under medical attention, which also correspond to a parcel of the set of people affected by the ailment.

Keywords: Leprosy. Control. Drug therapy combination. Neglected disease. Public policy. Deficiency evaluation. 


\section{Resumo}

Face às sucessivas dificuldades terapêuticas para o controle da hanseníase, a aplicação da poliquimioterapia nas últimas décadas fez surgir a expectativa de cura dos doentes e eliminação da doença como problema de Saúde Pública. Progressivamente obteve-se redução da prevalência, porém sem aparente impacto sobre a transmissão, o que vem levando, reconhecidamente, à necessidade de sólidas avaliações de respectivas evidências epidemiológicas como subsídio para intervenções resolutivas. Nesse sentido, apresenta-se estudo quali-quantitativo retroanalítico combinado ao enfoque diacrônico prospectivo, baseado na associação das técnicas de revisão documental e análise de conteúdo, envolvendo as fases sucessivas de montagem do esquema operacional, execução da estratégia de busca, aplicação de critérios, seleção de estudos, extração e processamento de dados, implementação do plano de análise e formulação final. A consecução adequada dos procedimentos aplicados permite obter e discutir a identificação de três principais cenários: - Eliminação da doença enquanto Problema de Saúde Pública (Doença Negligenciada); Aspectos Terapêuticos (Resistência; Recidiva; Não aderência; Persistência) e Complexidade (complicações e incapacidades físicas). As conclusões atingidas indicam, principalmente, que as realidades do controle atualmente vigente da hanseníase sob poliquimioterapia continuam precisando ainda serem manejadas com rigor, inclusive por terem alcançado apenas uma fração fragmentária dos doentes atendidos, os quais, por sua vez, também correspondem a apenas um segmento do conjunto de pessoas acometidas.

Palavras-chave:Hanseníase. Controle.Quimioterapia combinada. Doença negligenciada. Política Social. Avaliação de Deficiência.
Introduction and objectives

Leprosy is a chronic illness, of infectious origin, whose infective organism is Mycobacterium leprae, alcohol-acidresistant bacilli of high infectivity and low pathogenicity in endemic areas. Clinically described in different ways, the illness had its diagnostic formulation established, for a little more than 50 years ago, in four defined ways-the indetermined one, tuberculoid, the borderline and the lepramatous according to the level of immune answer. All of them present, in common, neural impairment, bigger or lesser, followed by dermatological manifestations, which vary since discrete and located erythematous hypochromic until extensive infiltrations, evolving with plaques, nodes and ulcers ${ }^{1}$.

Throughout the centuries, these injuries were identified as the basis of the physical deformities and disabilities which are present in most of the advanced scenarios, strongly entailed with stigmas of rejection and ostracism and of social, economic and religious origin, which had directly contributed for the exclusion of the carrier disease, from the social contact, in order for its consequent isolation of integrated health services2. Everything here mentioned means the additional barriers related to the respective therapeutic failure that has accumulated ${ }^{3}$.

Taking into account the increased frequency of microbiological resistance reports to isolated drugs in use for the respective treatment, a study group of the World Health Organization ${ }^{4}$ recommended, 30 years ago, for the first time, the adoption of the multidrugtherapy (MDT) as election route. It was characterized by the application of two basic principles, independent of the clinical form (or, in terms that became current, of the operational classification, i.e., if pauci- or multibacillary). The first one consists in the drug association of at least one bactericidal agent and a bacteriostatic agent. The second one is related to the administration form; therefore, it always combines the self-administration (by the 
sick person itself) and the supervised one (by the health professional).

The set of consequences, potentially favorable, made the enthusiasm of many people rapidly surpassed the caution of the evidences of efficiency and effectiveness ${ }^{5}$ defenders. Less than one decade, the procedure has become a worldwide sectorial public policy, that incentived the strategy of the illness elimination as a problem of Public Health for the World Health Organization, and reached security enough to even define goals of prevalence reduction (for less than a case for each ten thousand inhabitants), and date for its occurrence $^{6}$, later postponed for repeated times?

"This was a sad experience about how the ministries of health can be deceived and strategies without solid scientific basis can be approved" ${ }^{\prime \prime}$.

The author also mentions about the institutional ex-director confession, that MDT was approved by the superiors without a manifestation of none technical public agency, due to it might have been perceived that, probably, there would be reserves; the proposal's authors (whose names did not appeared, until the present date, to the surface of the public domain), they have felt a lack of establishment and, instead of correcting, they decided deviate the existing standard procedure for such situations.

A series of strategies were applied, by removing sanitary consolidated concepts until now. As pointed out by $\mathrm{Naafs}^{9}$, a treatment that brought few benefits to the leprosy patients and can, also, put in risk the adequate control and treatment of leprosy was adopted. Such facts had eliminated the installed capacity to supervise and to know what really happened in epidemiologic terms ${ }^{10}$. Some authors affirm that many endemic countries took administrative measures destined to hide the revelation of the true numbers of the detection of leprosy patients; because this would be politically inconvenient to them ${ }^{11}$.
As a result, several information services were demoralized and the processes formation of competent professionals discontinued, but the real world continued to manifest with persistence, and even ascension of the incidence curve ${ }^{12}$. Epidemiologically, is preoccupying the lack of effect about the transmission of the bacilli, argued by some people ${ }^{13}$; however, as a result of the most consequent detection to the growth of the assistance service capillarity, such hypothesis, remains waiting to the demonstration, even so it makes use of improved viability procedures of application and generation of trustworthy information, as demonstrated by Opromolla et al. ${ }^{14}$ in a classic investigation performed in our area, when quantifying the called epidemiologic iceberg of the illness. Previously, the available evidence suggests that the implied trends of the incidence were affected only a little bit ${ }^{15}$.

The impact of this few decades of elimination period has brought to the present time, after many medical and institutional discussion, the return of the illness to the previous levels, in which was a low priority for the sectorial directors and unprovided of adequate and accessible assistance and attendance, for leprosy patients and communicating ${ }^{16}$.

As a result, in the present time, national and international organizations, over all the World Health Organization ${ }^{17}$, are acclaiming the efforts to the recognized necessary reconstruction of the solid basis control. It is regarding to undertake careful evaluations, directed to the strategies that integrate institutions, responsible for the formation of health professionals, to the rendering services net, so that they interfere as reference groups of education and research in the area.

This, in other terms, means to overcome different conceptions and practices that, wrongly, still circulate between us, since the defense of vertical isolated programs up to the understanding about what should be prescinded of the specific ability to empower the extensive action, inside of our Unique 
System of Health (SUS) - undoubtedly the most democratic existing, given its universality, completeness, hierarchize and regional principles and procedures ${ }^{18}$.

In this context, a lot have been analyzed as the covered trajectory ${ }^{19}$, counting currently with a relatively abundant scenario of technical initiatives, focusing to explore different scenes that can show us as we are going to live in the next years. The objective of the present text was to contribute in this direction, recovering recently available information about the subject in the international specialized literature, regarding to:

- Proceed to the systematic retroanalysis study about the control evolution of leprosy, under the MDT strategy;

- Identify mistakes practiced in the execution of the respective measures, behaviors and procedures;

- Explore the introduction possibilities, between us, of new operational and technological resources to the intervention, as reference in the area.

\section{Methods}

This is a retroanalysis quantitative assay, combined with a prospective diachronic focus, formulated from the association of the documental revision techniques and content analysis ${ }^{19,20}$.

We assumed, from what has been affirmed by Almeida Filho ${ }^{21}$, that, in research "object and method are mediated (or mutually 'anchored') by a third term, the scientific praxis' and continued with Minayo et $\mathrm{al}^{22}$, when recognized that there is the "way of the thought" being required the personal mark of the researcher in the form to articulate the facts, theories and findings, in a subjectification and objectification dialectic. In the Baum words ${ }^{23}$, the methodologies for research in health "must be diverse and selected according to the problem investigated: if we would accept the nonexistence of only one correct form to see the world, our methods must firstly explore than blaming the diversity."
The bibliographic revision was assumed according to Vieira, Saad-Hossne ${ }^{24}$, as a process that results in an organization of highlighted issues in the specialized literature about certain subjects, allowing an "extensive look of relevant findings, in which the empirical studies do not do."

The first phase of viability was implied in the expression of a fluent title ("leprosy control") and, after that, in the isolation of a key-expression (MDT - multi drug therapy). Thus, the access to the secondary adopted sources was skilled, using the PubMed basis, the Virtual Health Library (BVS), Academic One File and Evidence-Based Medicine Reviews (because they are fluent and accessible), referring to the period between 2005 and 2011, getting reference to the 85 primary texts. Only when localized, they were placed for consideration, as praised by Thomas, Nelson ${ }^{25}$. Therefore, was accepted what was established by the American Association of Psychology ${ }^{26}$ that recognizes in that level publications that: a) conclude researches that were not published previously; b) were revised by interPair systems before being accepted for a certain period of time and/or; c) are able to be filed i.e., they can be recovered by stipulated reference. They have turned into observational end units, besides official institutional sectorial publications, the 27 technical scientific texts published in the international periodics that have resisted to the submission to the following criteria of inclusion:

- mentioning to ours object(s) of interest, namely: a) control of leprosy; b) MDT; c) relations between these two categories;

- expressed in contemporaneous languages and of understanding by the university area of the country (Portuguese, English and French);

- present under technician support of paper as well as under computer-based resources, which means online, or as a digitized file form;

- representative of current and updated databases, operated from thematic and definitely pertinent limits. 
- From the data storage with the technical described elements, as well as with comments and personal notes, it was possible to list the references, grouping them for subject and chapter of entrance, better guiding the consequent use of them, as research material, and to the end, the control of the bibliographic citations in the body of the text.

The contend analysis procedure was adopted as the set of research techniques, that aim to critically comprehend the direction of the communications and respective contents, manifested or latent, using different resources to reach encoded meanings, chosen, as Chizzotti remembers $^{27}$, in accordance with the material under analysis, the objectives of the research and the ideological and social position of the analyzer - and adequate for the lexical, categoric, of enunciation and of connotation analysis, or more: [...] using of any other innovative form [...].

In fact, admitting the structure notes of a work of the area, lately republished in Portuguese in an European edition ${ }^{28}$, was used the methodological sequence understanding by the following successive phases: a) exploratory and immediate contact with each one of the shared texts; b) the second atentive and productive reading, to transcend the spontaneous and direct look, due to structure in self concepts; c) categorical apprehension of knowing/ acting of the literal understanding, seeking for the main idea of each segment under study, isolating it to the side of the others, due to compose a list of subjects or thus recovered items; d) execution of the analysis plan leading to a contend formulation of the revision ${ }^{29}$.

\section{Results}

The MDT does not constitute just the only permissible way of treatment of leprosy, but is overall an association of sanitary strategies that reached expressive reduction of the leprosy patient number in the world.
This, however, was obtained by a very heterogeneous set of resources and procedures that, extremely consistent controversies are left regarding to how is going to be the international scenario that will remain to the end.

Chart 1 contains the indication, as mentioned in the current pertinent technical literature, of the main categories formulated of scenarios related to the leprosy control by MDT. As indicated, the most general and which has attracted most attention from health surveillance physician, epidemiologists and health managers, is related to the already mentioned question of the illness elimination, while problem of public health, there is involved the dimension if it is neglected or in extinguishing ways. On the basis of this controversy, are detached aspects strictly therapeutical involved, consisting, thus, in the second scenario to be argued. Finally we still need to consider the third scenario, the one of the manifestations of everything that were presented: the complexity, the complications and the consequent physical disabilities. Such situations are argued as follow, due to contextualize them from as they are conformed.

\section{Discussion}

\section{Elimination of the illness while it is a public health problem (neglected illness)}

This reality is the object of the scenario analysis, only computer based, undertaken by Meima et al. ${ }^{30}$. Appealing for the application of the computerized program to the "best available data in the world," the impact of the current strategy for the elimination of the disease in its incidence and the evaluation of the maintenance failure consequences of this strategy are investigated. It is methodologically guessed that the interest and the priority in the dealing of disease - considered eliminated in the most part of the world - continue to be the same to the citizens and authorities throughout the time and, as a result, the 
Chart 1 - Main scenarios related to leprosy control under multidrug, considering mentions in the present technical pertinent literature.

Quadro 1 - Principais cenários relacionados ao controle da hanseníase pela Poliquimioterapia, a partir de menção na literatura técnica pertinente atual.

1. Disease elimination while health public problem

2.1. Resistance

2. Therapeutic aspects:

2.2. Recurrence

2.3. Non-adherence

2.4. Persistence

3. Complexity, complications and physical disabilities

intensity of the premature diagnosis and the treatment by PQT remain constant. The estimated gotten is that the reduction, by half, of the incidence current values will happen for decades varying between a minimum of 5 and a maximum of 50 years, with an annual decline foreseen of the incidence of 2 to $12 \%$, depending on factors as calmetization of susceptible and speed of the bacilli dissemination into the populations. It is distinguished, then, that the control relaxation is unjustified, due to the uncertainty concerning to the decline rate, and the adverse effects of bigger delays in the detention: in synthesis, is recommended that a perspective of a long term intervention should be adopted.

Such assertive confirms what Evans ${ }^{31}$ predictively already announced, regarding that the leprosy control, as of the other infectious diseases, to be led in realistic bases, must consider the co-morbidities, disabilities and mortality as first priority; the infection control properly said as second priority and the presence control and the agent environmental dissemination as third, and only word about terms and activities of "elimination" and "eradication."

So that is better situated the conquered nomenclature that recognizes leprosy as "neglected disease" (ND). The Ministry of Health $^{32}$ recognizes the ND as those "that not only prevail in poverty conditions, but also contributes for the maintenance of the inequality scenario, once that they represent strong obstacle to the countries development."
More recently, the ND have been identified by the federal authorities ${ }^{33}$ as "extincted infectious diseases." The mentioned reason for this semantic substitution was referred as a need of change, of a negative connotation to a positive one, in the relation of the governmental agencies and the respective diseases - it is about the dislocation of the disrespect confession and negligence by the right opposite one: devotion and advance, that had resulted in the current stage of pre-disappearance in which they would be found. The new term clearly understands leprosy, malaria, filariosis, Chagas disease, onchocerciasis, geohelmintiases, trachoma, tuberculosis and congenital lues, that, together, attack more than a billion people, what means to say that they attack approximately one of each six persons of the whole alive Humanity. Here it is a scenario whose magnitude, therefore, cannot be ignored.

\section{Aspects more strictly therapeutic}

The recurrence seems to be the biggest threat that we can run, in terms of the leprosy therapeutic scenario. As it is about a chronic disease and highly dependent on the constitutional capacity of the host defense, the reappearance of clinical and/or laboratorial manifestations during the entire life of the sick person is a risk that must be strongly avoided, which aggravates more and more, while the factors connected to the etiologic agent and to the treatment would favor the etiologic agent. 
Current stories lead to believe that the prospection of this scene would not be much threatening, due to they inform that the occurrence of this condition would not be so frequent. The observational process circumstances can, however, answer for certain part of these results. In this order of facts, Poojabylaiah et al. ${ }^{34}$ got gross rate of recurrence prevalence of $1.84 \%$ between leprosy patients with complete and successful treatment of MDT, during 18 years, what corresponds to an average per capita of $7.13 \pm 1.25$ years. They were included in study, however, only 163 from 300 leprosy patients in the studied period, so that as the authors say, "we presume that the rates would be bigger if all had been evaluated". Even though, recent reports have revealed that recurrences of $1636 \%$ between multibacillary leprosy patients, with raised bacterioscope indices, were observed after conclusion of two years of MDT ${ }^{35}$.

These terms have its basis as it turns out, easily, that since the first successful assays with dapsone, in 1943 - in Carville, by Faget et al. ${ }^{36}$, the treatment of leprosy is known by the recurrent chronicle, of the escape from the multidrug-resistance (MR) of the drugs successively introduced. In fact, 10 years later, appeared the reports of the first occurrences of the mentioned MR, leading, two decades later, to the associated use of the rifampin, also pioneering, in national level in Brazil ${ }^{37}$. But only five years later, Jacobson and Hasting ${ }^{38}$ demonstrated an experimental case of leprosy resistant to rifampin. Such findings were reached by the use of the Shepard technique of bacillary growth in animal model but currently is already expected the availability of biomolecular resources to identify the mutants related to the dapsone, rifampin and ofloxacin ${ }^{40}$.

Concrete elements were made feasible for the continuous epidemiological surveillance of sentinel health event cases of MR, not only secondary but also primary, being, in these cases, MR in leprosy patients without the previous ingestion of specific drugs, in such way that in 2006, the World Health Organization organized of a world-wide net of capable and available laboratories to research MR in leprosy ${ }^{41}$. Implanted in 2009, it collects systematically data of six endemic countries: Brazil, China, Colombia, India, Miamar and Vietnam. In the inform of $2010^{42}$, are mentioned reports of 887 recurrences, of which 213 (24\%) tested for MR, had positive results to approximately $10 \%$ of them.

Can the non-adhesion be responsible for these numbers? Between the generating factors of this, the facts reported are about the drugs, the leprosy patients and the health services, but also schooling, gender, social class, wage level and cultural manifestation, which is the main requirement of physical presence in the service for the ingestion of the medicine and, therefore, the necessity of work absence. With effect, Kar et al. ${ }^{43}$ had confirmed this reason as responsible for $33.07 \%$ of the investigated cases by them, followed by adverse reactions to the drugs (25.98\%) and social stigma (18.11\%).

Foss et al. (2010) ${ }^{44}$ add, in the Brazilian case, the constant migration of the North States population to the South, especially frequent in the poorest segments of the society. They assure that, is very common that people initiate the treatment in a certain place and, later, they move to another place, and consequently taking to the biggest disease dissemination and the epidemiologic data imprecision. Such facts are worrying, as already mentioned, due to the supervised ministration is an identity component of this treatment.

One of the most argued issues in the medical scope of the MDT mentions about the shortened duration of the treatment, feasible, over all, due to its detached bactericide action: only the first dose of rifampin would be capable to kill $99 \%$ or more than the viable organisms and would become the sick person in two days not infectious, inhibiting per some days the reproduction of the rare survivors ${ }^{45}$. These, however, as it was demonstrated in tissue preparations, have presented persistence in the host, even if passed a very superior time 
to the year of the treatment duration, for the multibacillary cases that decimate the majority of them. The viable $M$. leprae are persistent, due to in a resistance research in the foot-pads of mice, they are sensitive to all the applied anti-micobactecidal agents, although the bactericidal tissue levels, a fact that justifies normative of the National Hansen's Disease (Leprosy) Program (HRSA), when recommending a follow-up after the patient discharge each six months, to the paucibacillary leprosy patients for five years, and to the multibacillary ones, 10 years $^{46}$. This fact makes the specialists taking sufficiently cautious regarding to public policies, when recommending that "any attempt of reducing the treatment duration of the patients with lepromatous leprosy in large scale must be made after careful assays with longitudinal studies" ${ }^{47}$.

\section{The scenario of the complexity and its manifestations}

The complexity scenario, the applied situations one, is pointed by Surveillance Guidelines, Leprosy Attention and Control, Ministry of Health, object of Directive $\mathrm{n}^{0} 3125$, the Minister's Office ${ }^{48}$. This is not about, only, establishing general coordinates, as normally, the official documents of the Brazilian government had been acting, letting procedures details in charge of guides and technical texts, which were published later, but yes, taking an incisive position, by the minudiscent strictness of the orientation destined to the managers and professionals, to the execution of the fortification of surveillance actions and the services organization, also based in the social mobilization.

In this direction, is indicated the MDT to the dapsone and clofazimin intolerance, they are isolated or agreed, for the use of the ofloxacin and/or the minocycline, supervised and self-administrated, for pauci and multibacillary, when indicated. Also we cannot consider as simple the mentioned situations of association with paradigmal harassments as AIDS and the competitiveness and hypokinesia diseases, as well as the proper peculiarities of leprosy, as the reaction treatment, to determine the use of pentoxifylline to benefit the cases with vasculitis predominance.

Events as the above mentioned lead us to frequent references to the higher complexity regional, state and national centers, what reinforce the, already mentioned, necessity of long-term horizon maintenance, especially, in what refers to the qualification of competent staff and to the development of appropriate technologies.

The complications are not only pointed to the diagnostic difficulties, frequently mentioned by some European authors ${ }^{49}$, but also to the posterior or aggravated organic injuries to the dermatological ones, including the ones resulting from a neural involvement. These affect the sensitive, motor and autonomic functions of the peripheral nerves, from sensory deprivations, motor limitations and the sweating affecting ${ }^{50}$.

In this direction, there is a scenario in evolution, as Sehgal et al..$^{51}$ present in their data, equally worrisome. Starting to the reaction analysis type 1 , they show the scenario in transformation in what is concern to the therapeutical use of corticoid: recommended previously by the World Health Organization to the application as a standard treatment for twelve weeks, in the current days it has a recommended duration for six to nine months, what it can seem reckless when the harmful effects are considered for long-term use of the drug.

We also remind some strategical facts to demonstrate that the weapons used in this fight are not so powerful as we are tend to believe. As a matter of fact, the recent knowledge is that the efforts destined to the prevention of disabilities, carried out during and after the period of the MDT application, resulted in success in only one of four cases, as well as we know, currently, the corticoids only prevent $60 \%$ of the cases, while the monofilaments of nylon are not superior than the other methods of evaluation, as the ballpoint pen.

A perspective of scenario for the control of leprosy in the next years, is pointed 
insistently by the Global Strategy, improved to the additional reduction of the leprosy load, quinquennial plan of the World Health Organization work to the period between 2011 and $2015^{52}$. Having as objective only to reduce the load of the disease for rendering services of quality, formulate repeatedly challenges, related to the evaluation and handling of the physical disabilities, in order to reveal that is entering in a period which prevention, diagnosis and treatment of these harassments will be found in the middle of actions and sectorial efforts.

In fact, approximately half of the strategical points to stimulate changes and define routes, consist in measures centered in these aspects, which are: a) attentive surveillance of the number of new cases with disability level 2; b) fortification of the actions in areas with high proportion of such cases and; c) adoption of directed procedures to the attendance of these people. The document registers, moreover, that is proposal, as basis for global aim of the progress surveillance of the developed managements after the beginning of the treatment, the proportion of leprosy patients with level 2 of disability between the new cases. They argue that is currently about the point that "centre its attention in deficiencies with crucial impacts over the people affected by the disease".

Nevertheless, this scenario of the disease reality in the next years is, unquestionably, one of the most serious, because the Leprosy Physical Disabilities (LPD) must grow in order to frequency and gravity, considering the current related data. $\operatorname{Cross}^{53}$ was charged to promote an evaluation of the coverage and quality of the services of LPD prevention and the results that he presents are almost alarming. It was made reference to 22 countries, whose set correspond to the addition of the nations where: a) one thousand cases occur more than once a year; b) there are reports of high prevalence; c) leprosy still is a significant problem.

The "generalized scarcity of information" is the first great gotten revelation, which is a fact related intrinsically with the second finding: the LPD prevention, implemented through national programs, presents "very spread". The respective cited reasons do not constitute newness as result, detaching: a) lack of qualified or, at least, trained professionals in the area; b) low governmental priority regarding to the leprosy control and, in addition, specifically to the LPD prevention; c) limited or lack of material resources; d) inadequate access to the services and e) mean therapeutical handling of reactions episodes.

\section{Conclusion}

It was possible to collect pertinent and consistent information in the technical literature concerning to the evolutive scenario of the leprosy control, under the MDT regime. Between the committed mistakes in this trajectory, it was evidenced that the control relaxation is unjustified, and should be necessary the opposite, while some adopted therapeutical pointers (resistance, recurrence, non adherence and persistence) place leprosy as ND, according to official nomenclature of the World Health Organization.

From rigorous quantitative procedures, the epidemiological evidences available indicate that we will continue to live with this disease for a long time, although the mistaken hope of many people.

Inside the operational resources for intervention in the area, the measures of epidemiological surveillance are differentiated, occurring in a context of increasing complexity, with an involvement, including, of social mobilization and differentiated therapeutical measures.

On the other hand, the complications of the disease deserve more attention day by day, due to its own peculiarities, or the associations with the modernity hazards, pointed by the competitiveness and hypokinesia. The physical disabilities, caused by the neural injuries, deserve special distinction, because the cares carried out, focusing the prevention during and after the PQT period, have presented success in only one of each four evaluated cases. 


\section{References}

1. Gonçalves A, Gonçalves NNS. Epidemiologia e controle da hanseníase: atualização conceitual. Revista Brasileira de Medicina 1980; 37(8): 414-7.

2. Awofeso N. Concept and impact of stigma on discrimination against leprosy sufferers - minimizing the harm. Lepr Rev 2005; 76(1): 101-2.

3. Gonçalves A. Carta ao Editor. Hist Ciênc Saúde-Manguinhos 2006; 13(4): 1065-6.

4. World Health Organization. Chemotherapy of Leprosy for Control Programmes: report of a WHO Study Group. Geneva; 1982. (WHO - Technical Report Series, 675).

5. Gonçalves A, Gonçalves NNS. A poliquimioterapia na hanseníase, com especial referência ao Brasil. Rev Bras Med 1986; 23(1-4): 5-10.

6. World Health Organization. Elimination of leprosy. Geneva; 1991. (Resolution of the 44th World Health Assembly).

7. Organisation Mondiale de la Sante. La dernière ligne droite vers l'emination de la lepre. Plan stratégique 2000-2005. Disponível em http://whqlibdoc.who.int/hq/2000/WHO_ CDS_CPE_CEE_2000.1_fre.pdf, 2005 (Acessado em 04 de Novembro de 2011)

8. Noto S. Why Brazil is doing this? Leprosy Mailing List. Disponível em http://www.aifo.it/english/resources/ online/lml-archives/index.htm (Acessado em 04 de dezembro de 2011)

9. Naafs B. Treatment of leprosy: science or politics? Trop Med Int Health 2006; 11(3): 268-78.

10. Fine PEM. Leprosy: what is being "eliminated"? Bull World Health Organ 2007; 85(1): 2-3.

11. Schreuder PAM. Give the leprosy workers a voice. Leprosy Mailing List. Disponível em http://www.aifo.it/english/ resources/online/lml-archives/index.htm (Acessado em 26 de dezembro de 2011)

12. Lima MSM, Pomini ACM, Hinders D, Soares MPB, Mello MGS. Capacitação técnica vs. comprometimento profissional: o real impacto no controle da hanseníase. Cad Saúde Colet 2008; 16(2): 293-306.

13. Penna ML, De Oliveira ML, Penna GO. The epidemiological behaviour of leprosy in Brazil. Lepr Rev 2009; 80(3): 332-44.

14. Opromolla DV, Nobrega RC, Gonçalves NNS, Padovani SHP, Padovani CR, Gonçalves A. Estimativa da prevalência da hanseníase pela investigação em demanda inespecífica de agências de saúde. Rev Saúde Pública 1990; 24(3): 178-85.

15. Saunderson PR. Leprosy elimination: not as straightforward as it seemed. Public Health Rep 2008; 123(2): 213-6.

16. Aquino DMC, Santos JS, Costa JML. Avaliação do programa de controle da hanseníase em um município hiperendêmico do Estado do Maranhão, Brasil, 1991- 1995. Cad Saúde Pública 2003; 19(1): 119-25.

17. Daumerie D. Independent evaluation of GAEL. Letter to the editor. Lepr Rev 2004; 75: 407-8.

18. Fleury S. Brazilian sanitary reform: dilemmas between the instituing and the institutionalized. Cien Saude Colet 2009; 14(3): 743-52.

19. Gonçalves A, Mantellini GG, Padovani CR. Leprosy Control: perspectives \& epidemiological and operational aspects. Rev Inst Med Trop Sao Paulo 2010; 52(6): 311-5.

20. Mantellini GG, Gonçalves A. A revisão e a análise como metodologias científicas conteudísticas. Inter Science Place 2009; 2(5): 1-13.

21. Almeida Filho N. A ciência da saúde. São Paulo: Hucitec; 2000.

22. Minayo MCS, Deslandes SF, Cruz Neto O, Gomes R Pesquisa social: teoria, método e criatividade. Petrópolis: Vozes; 1994.

23. Baum F. Researching public health: behind the qualitativequantitative methodological debate. Soc Sci Med 1995; 40(4): 459-68.

24. Vieira S, Saad-Hossne W. Metodologia científica para a área da saúde. São Paulo: Campus; 2001.

25. Thomas JR, Nelson JK. Métodos de pesquisa em atividade física. Porto Alegre: Artmed; 2002.

26. American Psychological Association. Publication manual of the American Psychological Association. Washington: 2001.

27. Chizzotti A. Pesquisas em ciências humanas e sociais. São Paulo: Cortez; 2001.

28. Bardin L. Análise de conteúdo. Lisboa: Edições 70; 2004.

29. Cohen JS, Biesecker BB. Quality of life in rare genetic conditions: a systematic review of the literature. Am J Med Genet A 2010; 152A(5): 1136-56.

30. Meima A, Smith CS, Van Oortmarssen GJ, Richardus JH, Habbema JD. The future incidence of leprosy: a scenario analysis. Bull World Health Organ 2004; 82(5): 373-80.

31. Evans AS. Ruminations on infectious disease epidemiology: retrospective, curspective, and prospective. Int J Epidemiol 1985; 14(2): 205-14.

32. Brasil. Doenças negligenciadas: estratégias do Ministério da Saúde. Rev Saúde Pública 2010; 44(1): 200-2.

33. Soares RCFR. Epidemiologia da Hanseníase. Programa XII Congresso Brasileiro de Hansenologia; 2011 nov 23-26; Maceió (Br). Bauru: Sociedade Brasileira de Hansenologia 2011.

34. Poojabylaiah M, Marne RB, Varikkodan R, Bala N, Dandakeri S, Martis J. Relapses in multibacillary leprosy patients after multidrug therapy. Lepr Rev 2008; 79(3): 320-4. 
35. Scollard DM, Adams LB, Gillis TP, Krahenbuhl JL, Truman RW, Williams DL. The continuing challenges of leprosy. Clin Microbiol Rev 2006; 19(2): 338-81.

36. Faget GH, Pogge RC, Johansen FA, Dinan JF, Prejean BM, Eccles CG. The promin treatment of leprosy. A progress report. Int J Lepr Other Mycobact Dis 1966; 34(3): 298-310.

37. Opromolla DVA. Contribuição ao estudo da terapêutica da lepra (hanseníase) [Tese de Doutorado]. Bauru: Faculdade de Odontologia de Bauru, Universidade de São Paulo; 1972.

38. Jacobson RR, Hastings RC. Rifampin-resistant leprosy. Lancet 1976; 2(7998): 1304-5.

39. Shepard CC. The experimental disease that follows the injection of human leprosy bacilli into foot-pads of mice. J Exp Med 1960; 112(3): 445-54.

40. Matsuoka M. Drug resistance in leprosy. Jpn J Infect Dis 2010; 63(1): 1-7.

41. Organisation Mondiale de la Santé. Pharmacorésistance de la lèpre: rapports de certains pays d'endémie. Weekly Epidemiological Record 2009; 26: 264-8.

42. Organisation Mondiale de la Santé. Relevé épidémiologique hebdomadaire. Weekly Epidemiological Record 2010; 29: 281-4.

43. Kar S, Pal R, Bharati DR. Understanding non-compliance with WHO-multidrug therapy among leprosy patients in Assam, India. J Neurosc Rural Pract 2010; 1(1): 9-13.

44. Foss N, Souza A, El-Azhary R. Leprosy in Brazil. International Journal of Dermatology 2010; 49: 589-97.

45. Sehgal VN, Sardana K, Dogra S. The imperatives of leprosy treatment in the pre- and post-global leprosy elimination era: appraisal of changing the scenario to current status. J Dermatolog Treat 2008; 19(2): 82-91.

46. Worobec SM. Treatment of leprosy/Hansen's disease in the early 21 st century. Dermatol Ther 2009; 22(6): 518-37.

47. Job CK. Report on a 10 year follow-up study of 2 lepromatous patients treated for 1 year with standard multidrug therapy. Indian J Lepr 2009; 81(3): 149-50.

48. Brasil. Portaria nº3125 de 07 de outubro de 2010: aprova as diretrizes para vigilância, atenção e controle da Hanseníase. Brasília: Ministério da Saúde; 2010.

49. Forno C, Häusermann P, Hatz C, Itin P, Blum J. The difficulty in diagnosis and treatment of leprosy. J Travel Med 2010; 17(4): 281-3.

50. Walker SL, Lockwood DN. Leprosy. Clin Dermatol 2007; 25(2): 165-72.

51. Sehgal VN, Sardana K, Dogra S. Management of complications following leprosy: an evolving scenario. J Dermatolog Treat 2007; 18(6): 366-74.

52. Organização Mundial Da Saúde. Estratégia Global aprimorada para a redução adicional da carga da Hanseníase. Brasília: Organização Pan-Americana da Saúde; 2010.

53. Cross H. Adding quality to leprosy control: prevention of disability. Lepr Rev 2010; 81(2): 138-43.

Received on: 03/20/12 Final version presented on: 12/16/12 Accepted on: 03/07/13 